\title{
Solar Energy Policy: Malaysia VS Developed Countries
}

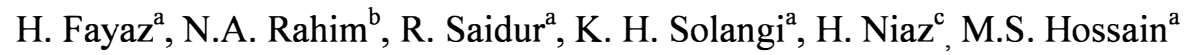 \\ ${ }^{\mathrm{a} D e p a r t m e n t ~ o f ~ M e c h a n i c a l ~ E n g i n e e r i n g ~}$ \\ ${ }^{\mathrm{b}}$ Centre of Research UMPEDAC, Level 4, Engineering Tower \\ Faculty of Engineering, University of Malaya, 50603 Kuala Lumpur, Malaysia \\ ${ }^{\mathrm{c} I n s t i t u t e}$ of Business and Technology (BIZTEK), City Campus Shahra-e-Faisal, Karachi, Pakistan
}

\begin{abstract}
Countries all over the world is enquiring and taking efforts to implement the environment friendly renewable energy to mitigate the negative impacts of fossil fuels on the environment and their fast depletion. To reduce the reliance on fossil fuels and environmental degradation, many countries have focused and formulated solar energy related policies to increase its share into energy mix. In this paper a review of the solar energy policies, implemented in the developed countries and Malaysia, are discussed as well as the discussion of successful existing solar energy policies in the developed countries. According to the 2010 BP Statistical Energy Survey, the world cumulative installed solar energy capacity was 22928.9 MW in 2009, a change of $46.9 \%$ compared to 2008 . After the review of literature, FiT, RPS and Incentives are found to be the most beneficial energy policies implemented by the developed countries. These policies create the paths to promote the development and implementation of renewable energy technologies. Also, the current policies related to solar energy in Malaysia are investigated and compared with developed countries.
\end{abstract}

Malaysia

Keywords: solar energy, developed countries, policy,

\section{INTRODUCTION}

Energy policy is a way strategy or manner; in which government decides to address the issues of energy development along with the development of the energy industry to sustain its growth; including energy production, distribution and consumption [1]. The attributes of energy policy may include legislation, international treaties and incentives to investment, guidelines for energy conservation, taxation and other public policy techniques. It plays a vital role to mitigate the impacts of global warming and crisis of energy availability [2]. Diverse policies have been developed and implemented to promote the use of renewable energy. These policies include feed-in-terrif (FiT), pricing laws, renewable portfolio standard (RPS), production incentives, tax credits, trading systems and quota requirements etc. [3]. Reduction of the reliance on fossil fuels, mitigation of environmental impacts of the energy sector and encouragement of new industrial development, are the main objectives of these strategies. Hence, among all those policies, the most popular are the feed-in-terrif (FiT) and renewable portfolio standard (RPS). Though, To make a choice for suitable policy, there exist a lot of debates regarding their effectiveness. For this, it depends on the circumstances and objectives of the countries that which RE policy can be suitable to implement. According to Ekins [4]
"No optimal model has emerged, and probably none will do so in the contexts that is shaped by different histories and cultures". To set the energy policy, there are many literatures, which target the particular policy for a country. However, in this paper authors discuss and compare energy policies for 4 countries around the world. It is expected that it will be very useful for policy makers, energy producing industries, research organizations and Government in Malaysia.

\section{UNITED STATES OF AMERICA}

According to industry reports, solar energy use increased at massive scale in 2008 in the USA and rest of the world. The Solar Energy Industries Association, "2008 U.S solar Industry Year in Review", found that U.S. 17\% of solar energy capacity increased in 2007, reaching the 8,775 megawatts (MW) total equivalent. Research and publishing firm, Clean Edge and the nonprofit Co-op America, gave the report that projects about $2 \%$ of the nation's electricity comes from concentrating solar power systems, while solar photovoltaic systems will contribute $8 \%$ of the nation's electricity. Those figures correspond to about 50,000 MW of solar photovoltaic systems and more than 6,600 MW of concentrating solar power [5]. United States of America has put several energy policies related to solar and other forms of renewable energy in action described as follows;

\section{1) Renewable Portfolio Standard (RPS)}

28 states of USA have adopted RPS mechanism, by which maximum production energy is required from renewable energy such as solar, wind, geothermal and biomass. To help utilities comply with their RE obligations, majority of the states which have RPS policy, allow the utilities to exchange renewable energy credits (RECs) or renewable energy certificates. There are three assumptions made, for the implementation of RPS policy program. First, an RPS policy is only considered operational according to the effective date of policy implementation, not the adoption date. Second, any RPS policy that became effective in either November or December is not coded as effective until the following fiscal year. For instance, if a state effectively begins a RPS program in November 2003, the value of their RPS variable equals zero from 1998 to 2003, and one thereafter. Third, they do not code any voluntary or "goal", based RPS policies as a mandated standard. 


\section{2) The formation Incentives}

It was first adopted as the Public Utility Regulatory Policies Act or PURPA in 1978. It was the requirement of the PURPA for utilities to purchase renewable electricity from qualified independent generators over long-term contracts. Unlike today's feed-in tariffs, which guarantee a premium for the renewable electricity delivered to the grid, PURPA payments were based upon the avoided cost of generating electricity from conventional sources. Under the PURPA from 1981 to 1990 , approximately $12,000 \mathrm{Mw}$ of renewable energy were installed around the USA.

For renewable energy technologies, in 1978 first Investment Tax Credits (ITC) was established. Residential tax credit was created for $30 \%$ of the first $\$ 2000$ invested in a solar or wind systems and $20 \%$ of the next S8000 invested by the Energy Tax Act of 1978; business tax credits for $15 \%$ of investment in a solar, geothermal and wind systems; and an excise tax exemption for gasohol, turned into a tax credit for ethanol. Regan Administration encouraged the Congress to allow the residential solar and wind investment tax credits to run out for the first time in 1995.

\section{3) Production tax credit}

For small large-scale wind projects a Production Tax Credit (PTC) of 1.5 cent/kilowatt-hour $(\mathrm{kWh})$ of electricity was created in 1992. For small large-scale wind projects a Production Tax Credit (PTC) of 1.5 cent/kilowatt-hour $(\mathrm{kWh})$ of electricity was created in 1992, based on up-front capital costs [6]. From 1986 to 1988, the business ITC for solar was reduced about $10 \%$. Installed PV capacity doubled in the U.S from the result of $30 \%$ increase and extension of residential and business ITCs for 3 years in 2005. The 2007-2008 political seasons capped off the tumultuous 30year ride for these tax credits. For struggling Wall Street banks after a 2-year political stand-off over extending the credits before their expiration at the end of 2008, Congress finally passed a tax-extenders bill in October as part of a financial bail-out package. Today, the solar industry has an extension of 8-years of the ITC. It seems the only thing consistent about the tax credits has been in consistency, when looking at the brief history of renewable energy incentives in the U.S.

\section{4) Target}

Solar hot water systems or solar-electric systems are being enjoyed by millions of Americans. About 83,000 solar thermal and solar electric systems were installed in U.S in 2007 [7]. 30\% of federal ITC has been the most important component, although state solar programs have played a key role in driving this growth. In the recent report of the ITC economic impact, over $6000 \mathrm{MW}$ of annual solar PV and solar thermal installations by 2016 could be resulted by and 8 year extension of the residential and business credits. Navigant projected that annual installations would have fallen to about $1500 \mathrm{MW}$ by 2016 ; If Congress had failed to extend the ITC in 2008 .

\section{France}

Globally, the position of France is fifth for production of PV energy. In 2009, the French electricity giant EDF announced that it will build the country's largest solar manufacturing plant with an initial annual capacity of more than 100 Megawatt Peak (MWp). At the end of last year, France committed to multiply solar power use by 400 in the coming 12 years. To double the share of renewable energy up to $23 \%$ by 2020 is the part of a larger plan for meeting the EU obligations and to compete with Germany, regarded as EU giant. [8].

\section{1) Feed-in tariffs (FIT)}

France uses FiT as a main measure to adopt PV in the country, issued in July 2006. In this, an obligation is put on the part of a utility to purchase electricity from renewable energy producers paying a tarrif set by public authorities and guaranteed for a specific time period. A FiT's value is the full price, which an independent power producer receives for any $\mathrm{kWh}$ of electric energy produced from renewable energy resources, including a premium above or additional to the market price but excluding tax rebates or other production subsidies, which government pays. In Europe and the USA, FiTs mechanism is primarily used to RES development and presently, they are being applied in 20 EU member countries.

Ministry of Industry is the legal framework for this measure in France. FITs are composed from a basic tariff, for nonintegrated PV systems (NIPV) and a bonus in the case of building integrated PV systems (BIPV). Table 1 summarizes the FITs' values for PV installations in 2009.

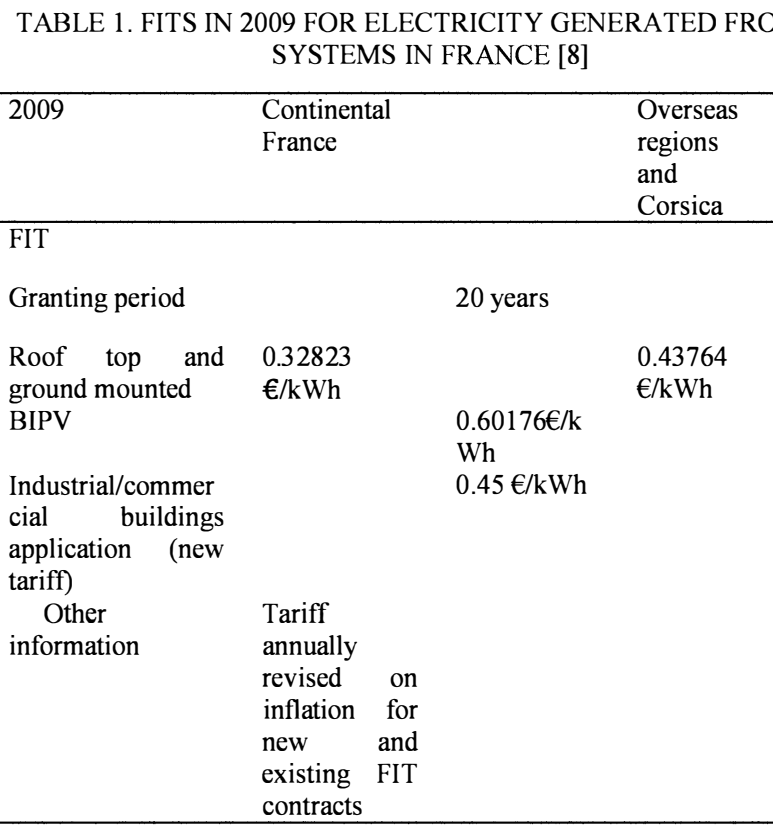

Before the revision in the normal review process, these tarrifs will remain valid until 2012. It is expected that PV cumulative installed capacity will increase from $1100 \mathrm{MW}$ 
in 2012 to $5400 \mathrm{MW}$ in 2020. Because of the long administrative procedures, in 2008 only $46 \mathrm{MW}$ were connected to the grid out of $105 \mathrm{MW}$ installed capacity [8].

\section{2) Incentive}

Tax incentives and green loans are beneficial in credit terms, and are the example of other additional supports to promote RE. The government grants a $50 \%$ tax credit on material cost at the main residence (maximum $€ 8000$ for singles and $€ 16,000$ for couples, valid until the end of 2012) for the PV systems $<3 \mathrm{kWp}$. Tax credit is not cumulative with FIT For PV systems $>3 \mathrm{kWp}$. Accelerated investment depreciation for companies and a reduced VAT of 5.5\% (if the equipped host building is more than two years old) are the other financial incentives.

\section{AUSTRALIA}

Mandatory Renewable Energy Target [9] program of 2001, aimed at encouraging $9500 \mathrm{GWh}$ of electricity generation from RE sources by 2010 , is built on by the Renewable Energy Target, announced in August 2009. In july 2009, estimated installed PV was $115 \mathrm{MW}$, which contributes an estimated 0.1 to $0.2 \%$ of total production despite the dry, sunny and hot climate, ideal of its utilization. The cost of solar panels is the reason for unreached grid parity because of higher cost per $\mathrm{kW}$ than other power sources. FiTs and other mandatory renewable energy targets are designed to enhance the commercialization of renewable energy in Australia. [10].

\section{1) Feed-in tariffs}

FiTs have been investigated in many territories and states Australia but this time only South Australia and Queensland have implemented schemes. Queensland's Solar Bonus Scheme pays small electricity customers (defined as customers that consume less than100MWh $\mathrm{yr}^{-1}$ ) AU\$ 0.44 $\mathrm{kWh}^{-1}$ from photovoltaic systems less than $10 \mathrm{kVA}$ for single phase and $30 \mathrm{kVA}$ for 3 phase systems until 2028 [11]. Albeit, small electricity customer must consume less than 160 MWhyr-1 Since South Australia has an identical scheme. In 2008, the Australian Capital Territory passed FITs legislation. 3.88 times the domestic electricity price is paid by the ACT scheme, which are equal to or less than $10 \mathrm{kVA}, 3.104$ times for systems greater than $10 \mathrm{kVA}$ up to $30 \mathrm{kVA}$, and 2.91 times for systems larger than $30 \mathrm{kVA}$. There is no FiT implemented in Western Australia to date but newly elected government has shown support for a WA FiTs sheme.

\section{2) Subsidies}

Solar PV technology is still 3-4 times the cost of gas-fired electricity. Consequently, despite significant government support programs, solar PV is estimated by recent projections to grow at an annual rate of $15 \mathrm{MW}$ (medium case) up to 2020 [12]. Utility scale thermal technology is under development, although $10 \mathrm{MW}$ demonstration plant is about to be commercialized, planned in Queensland. Large- scale solar thermal remains an expensive proposition as being a stand-alone technology therefore it limits the commercial diffusion to subsidized programs such as the Solar Flagships program, earmarking AU\$1.6 billion over 6-years for the support of construction and demonstration of large-scale solar power stations, with an ultimate target of $1000 \mathrm{MW}$ [13].

\section{3) Target}

Australia is at the cross-roads in terms of how to meet its future energy requirements in an increasingly 'carbonconstrained' multilateral policy environment [14]. A shortfall in available electricity is expected with few years at the current levels of generation. Due to the Carbon Pollution Reduction Scheme White Paper, the publication of the Garnaut report and announcement of an Emissions Trading Scheme to commence in 2010 and announcement of a national mandatory renewable energy target of $20 \%$ share of electricity supply in Australia by 2020, Federal policy is beginning to change.

\section{SOLAR ENERGY POLICY OF MALAYSIA}

Throughout the years, the government of Malaysia has formulated numerous energy-related policies to combat the climate change and ensure the energy security. Pragmatic energy policies since last three decades have facilitated a clean energy development path. The five-fuel policy was introduced in $8^{\text {th }}$ Malaysian Plan which was extension of four fuel diversification policy in which renewables as a fifth fuel was included. Contribution of $5 \%$ of the country energy mix with RE by year 2005 was targeted with mitigation of 70 million tones of $\mathrm{CO}_{2}$ over a time period of 20 years. Parallel to this, Small Renewable Energy Program (SREP) which was launched in May 2001 under the initiative of the Special Committee on Renewable Energy (SCORE) to support the government's strategy to intensify the development and utilization of $\mathrm{RE}$ as the fifth fuel resource in power generation, which is also stipulated in the objectives of the Third Outline Perspective Plan (OPP) for 2001-2010 and the 8thMalaysia Plan (2001-2005) (8MP). Facilitation of the expeditious implementation of gridconnected RE resources-based small power plants is the primary focus of SREP [15]. Further, in the 9th Malaysia plan the utilization of RE resources and efficient use of energy were emphasized.

The establishment of the Ministry of Energy, Green Technology and Water, shows Malaysia's seriousness that 'clean and green' is the way forward towards creating an economy that is based on sustainable solutions. The National Green Technology Policy is comprised of four pillars - (1) seek to attain energy independence and promote efficient utilization (2) Conserve and minimize the impact on the environment; (3) Enhance the national economic development through the use of technology; and (4) improve the quality of life for all. It will also be the basis for all Malaysians to enjoy an improved quality of life, in line with the national policies, including the National Outline 
Perspective Plan, where the growth objectives for the nation will continue to be balanced with environmental consideration. For the decades to come, fossil fuels are expected to be the main source of energy, where renewable energy sources such as solar, biofuels, biomass, geothermal heat and wind are expected to double until 2030. Recently, in $10^{\text {th }}$ Malaysian Plan RE share is set to $5.5 \%$, and is projected to $5.9 \%$ by 2030 [16].

Table 2 shows the rough estimation of the RE potential in Malaysia. Hydropower and solar PV are with highest potential due to Malaysia's geographical terrain with many large rivers suitable for dam projects and its tropical climate with plenty of sunlight.

TABLE 2. RENEWABLE ENERGY POTENTIAL IN MALAYSIA [15]

\begin{tabular}{ll}
\hline Renewable Energy & $\begin{array}{l}\text { Potential } \\
\text { (MW) }\end{array}$ \\
\hline Hydropower & 22,000 \\
Solar PV & 6,500 \\
$\begin{array}{l}\text { Biomass/biogas (oil palm mill } \\
\text { waste) }\end{array}$ & 1,300 \\
$\begin{array}{l}\text { Mini-hydro } \\
\text { Municipal solid waste }\end{array}$ & 500 \\
Wind & 400 \\
& $\begin{array}{l}\text { Low wind } \\
\text { speed }\end{array}$ \\
\hline
\end{tabular}

However, Malaysia is rich in solar power as compared to neighboring countries as Solar is the second renewable source after biomass, which gets a big boost. In this case, the policy for developing countries for instance is always available as a mechanism to enhance the utilization of RE, which include solar, apart from the local National Energy Policy drafted since the Fifth's Malaysia Plan [17].

\section{1) Energy Research and Development $(R \& D)$ Enhancement}

At present, domestic hot water system, drying of agricultural produce and water pumping are the main applications of solar energy. Malaysia has abundant sunshine with the average daily solar insolation of $5.5 \mathrm{~kW} /$ $\mathrm{m} 2$, which is equivalent to $15 \mathrm{MJ} / \mathrm{m} 2$. PV-generated electricity, whether standalone or grid connected, is electricity generated at point of use. If generation and transmission losses of the conventional system are factored in then 1MW of PV generated electricity is equivalent in fuel saving to about $4 \mathrm{MW}$ of conventional electricity. To set a target of about $10 \mathrm{MW}$ of grid connected photovoltaic system for Malaysia may be quite feasible.

For instance, Monier Malaysia, a local company launched last years when oil prices peaked, which specializes in energy efficient roofing solutions, has got systematic growth of demand for its solar product. Malaysia managed to invest US\$4 over the past three years resulting in creation of
11,000 jobs. The RE policy provides the rules and funds to make RE an important component of the country's energy mix, overcome technological barriers, address existing market failures, create a level playing field for these technologies and drive down costs. But the role of public policy is so important, where it is not defined enough. The efforts must be taken by the government to generate public will in support of the renewable energy agenda. So far, the arguments in favor of supporting RE have been overwhelmingly environmental [3 and 17].

The right support mechanisms must be in place to create the market, for any green technology industry to succeed. One of the key obstacles is the prohibitive pricing of RE that gives households and businesses little incentive to adopt the technology.

\section{2) Incentives for Renewable Energy Investment}

Malaysia is blessed with multiple RE resources, such as biomass, biogas, mini-hydro and solar, that will be leveraged to ensure a more sustainable energy supply. However, despite rigorous initiatives, the renewable target set out under the Ninth Plan period was not achieved. Under the Tenth Plan, several new initiatives anchored upon the Renewable Energy Policy and Action Plan will be undertaken to achieve a renewable energy target of $985 \mathrm{MW}$ by 2015 , contributing $5.5 \%$ to Malaysia's total electricity generation mix. Amongst the measures taken will be:

- Introduction of a Feed-in Tariff (FiT) of 1\% that will be incorporated into the electricity tariffs of consumers to support the development of RE. This mechanism allows electricity produced from RE to be sold to utilities at a fixed premium price and for a specific duration; and

- Establishment of a Renewable Energy Fund from the FiT to be administered by a special agency, the Sustainable Energy Development Authority, under the Ministry of Energy, Green Technology and Water (KeTTHA) to support development of RE [18].

\section{CONCLUSIONS}

Solar energy is one of the most promising renewable, switching to solar energy can be a viable move. It is evident from the literature that all the countries have specific solar energy policies to utilize solar energy for power generation. The solar energy policies in developed countries are well designed to enhance electricity generation from solar power significantly. Feed-in Tariff, Tax exemption, renewable portfolio standards subsidies, formation incentives are the main policies adopted by developed countries.

Malaysian government has formulated a series of policies for the promotion and insurance of the rapid, effective and smooth development of renewable energy, such as FiTs, laws, regulations, economic encouragement, technical research and development, industrialized support and renewable energy model projects, etc.

The PV market in Malaysia is still extremely small as compared to other developed countries. Under the Tenth 
Plan, several new initiatives anchored upon the Renewable Energy Policy and Action Plan will be undertaken to achieve a renewable energy target of 985 MW by 2015 , contributing $5.5 \%$ to Malaysia's total electricity generation mix. It is found that there are few limitations in Malaysia's renewable energy policies, such as less encouragement in lower level; lack of coordination and consistency in policy framework; lack of regional policies innovation; inadequate investment in technical research and development; incomplete and unhealthy financing and investment system etc. It is forecasted that in near future sustainable energies in Malaysia will play significant role because country is struggling to replace fossil fuels with alternative energy sources which are truly clean, renewable and safer.

\section{REFERENCES}

[1] DPS. Department of Political Science, Retrieved on March 2010, available at:http://www.politics.ubc.ca/index.php?id=12547,March2010. 2010.

[2] EPD. Energy policy defination. Retrieved on June 2010, Available at:,http://www.tutorvista.com/ks/energy-policydefinition.March2010. 2010

[3] K.H. Solangi, M.R. Islam, R. Saidur, N.A. Rahim, H. Fayaz. "A review on global solar energy policy", Renewable and Sustainable Energy Reviews, 2011; 15: 2149-2163.

[4] P. Ekins, Step changes for decarbonising the energy system: research needs for renewables, energy efficiency and nuclear power. Energy Policy 2004; 32 1891-1904.

[5] USDE. Study: Solar Power Could Provide 10\% of U.S. Electricity by 2025. Retrieved on May 2010, available at:http://apps1.eere.energy.gov/news/news_detail.cfm/news_id $=1183$ 5. 2010 [cited.

[6] P.S.L. Gipe, Energy Equity: Diversifying the market with new incentives.,. Inside Renewable Energy, 2008 (Podcast retrieved from). 2008.

[7] BMU. BMU, 2008a. Electricity From Renewable Energy Sources What Does it Cost Us? Berlin, Germany. 2008a.

[8] L. Dusonchet, E. Telaretti, Economic analysis of different supporting policies for the production of electrical energy by solar photovoltaics in western European Union countries. Energy Policy 2010; 38(7): 3297-3308.

[9] MRET. Australia, G.oThe Basics.Office of the Renewable Energy Regulator Government of Australia, 2009e(Canberra,Australia). 2009 e.

[10] Plan SHAC. Australian government department of climate change and energy efficiency. . 2010.

[11] QDME. Queensland Department of Minesand Energy,2008.SolarBonusScheme. $\quad / \mathrm{http}: / /$ www.dme.qld.gov.au/Energy/solar_feed_in_tariff.cfmS. Accessed August 2010. 2010.

[12] CME. Renewable Energy Projections:2009-2028. Carbon Market Economics (CME) Pty Ltd.,Australia, 2009. Available at: http://www.aemo.com.au/planning/419-0032.pdf. 2009.

[13] CEI. Clean Energy Initiative: Department of Resources, Energy and Tourism, (Canberra,Australia). 2009.

[14] S. Becken, Frampton C.,Simmons D. Energy consumption patterns in the accommodation sector-the New Zealand case. Ecol Econ ;39:371-86. . 2001.

[15] T.H. Oh, S.Y. Pang, S.C. Chua, Energy policy and alternative energy in Malaysia: Issues and challenges for sustainable growth. Renewable and Sustainable Energy Reviews 2010; 14(4): 1241-1252.

[16] F. Sulaiman, Renewable Energy and its Future in Malaysia: A Country Paper. Proc. of Asia-Pacific Solar Experts Meeting, Islamabad, Pakistan. 1995.
[17] M.P. Koh,W.K. Hoi, Renewable energy in Malaysia: A Policy Analysis. Energy for Sustainable Development Volume VI No. 3: 31 39. 2002.

[18] 10th MP, Tenth Malaysia Plan 2011-1015, Published by 'The Economic Planning Unit Prime Minister's Department Putrajaya 2010. 